\title{
Do Small Indonesian Companies Have a Better Performance in the Stock Market than Larger Ones?
}

\author{
Gerardo "Gerry" Alfonso Perez" \\ ${ }^{1}$ University of Cambridge, UK \\ Correspondence: Gerardo "Gerry” Alfonso Perez, University of Cambridge, UK.
}

Received: July 10, 2017

Accepted: August 3, 2017

Online Published: September 11, 2017

doi:10.5430/ijfr.v8n4p1

URL: https://doi.org/10.5430/ijfr.v8n4p1

\begin{abstract}
Company specific characteristics, such as size, might have an impact on stock performance. In fact, there is an extensive literature supporting the existence of a small capitalization effect stock in many markets, such as the U.S. (Fama, 1992), UK (Andrikopoulus, 2008)) and Thailand (Alfonso, 2016). In this article the Indonesian case is presented. Indonesia has a growing economy and financial markets and is one of the ASEAN countries. The performance of small and large capitalization stock from 2010 to 2016 was analyzed in this article. The results, at a $5 \%$ confidence level, indicate that the assumption that the returns from small and large capitalization stocks for that period being the same cannot be rejected. The result was consistent when analyzing the entire period or when analyzing every single year independently. The test used to compare the performance of small and large capitalization stocks was the Wilcoxon test. The risk adjusted returns were also compared with the conclusion remain the same. The returns of the index as well as the logarithmic returns, during the same, period did not appear to follow a normal distribution. Normal distribution is not an assumption required by the Wilcoxon test. The idea that small capitalization stocks outperformed large capitalization stocks cannot be supported by either the results of the statistical tests or by the actual returns during that period. The finding supports that there are significant differences between the behavior of the stock market in Indonesia and other comparable countries like Thailand.
\end{abstract}

Keywords: frontier market, Indonesia, small capitalization, stock

\section{Introduction}

In some countries it has been observed that listed stocks with relatively small market capitalization tend to outperform companies with large capitalization (Collins 1990). There is no entirely satisfactory of this occurrence and might be a country specific event. Intuitively there are some factors that might explain such issue. For instance, large companies are likely to attract a higher degree of attention and a larger amount of analyst covering such company. The larger the amount of analysts covering a stock, all else equal, the more difficult it is to find previously unknown information with investment value on the company. As outperforming becomes more difficult speculative investors move to those shares that might offer more information discovery opportunities. Another explanation, see for instance (Switzer 2012) is the concept that perhaps that outperformance is related to small capitalization companies being riskier than large capitalization stocks and investors demanding hence a higher expected return on those stocks in order to invest. The corporate governance issue in the case of Indonesia has been mentioned by some authors like (Nurazi, 2015).

Then, there is the issue of comparability across markets. The existence of a small capitalization effect in a given country cannot immediately be generalized to other countries, particularly those with radically different economies. The specific case of the Indonesian stock market was analyzed in this article. Indonesia is typically categorized neither as a developing or developed country but as a frontier country. May different countries are categorized as frontier countries and they are far from a homogenous group but they have some basic similarities. They tend to have economies that can potentially have very substantial growth rates in the future but they are also associated with higher investment risk due to a multitude of factors. There tends to be much less research regarding frontier countries than other countries. One interesting article that mentions the risk reward trade off, for a particular sector, in the Indonesian stock market is (Moh, 2014). 
Indonesian stock market

Relatively little literature is available covering the Indonesian stock market, particularly when compared to more economically developed countries. (Pasaribu, 2009) found that there is a small capitalization effect in the Indonesian stock market for a sample from 2003 to 2006 . The results from this article seem to disagree with the result obtained in (Passribu, 2009). Two possible reasons behind this discrepancy could be that in this article a longer data series is used and also to methodological differences such as using an index approach. One factor to take into account when analyzing a stock market in a given country is the efficiency of the stock market. (Andrianto, 2016) concluded that there are indications to show that the Indonesian stock market is weak form efficient. Some scholars have mentioned the lack of interest of the local population regarding speculative investments as a potential issue for the development of the Indonesian stock market (Browne, 1985) and the potential impact on the efficiency of Indonesian stock market. Indonesia presents several peculiarities as an economy with a population in excess of 260 million dispersed along a very large amount of islands and multiple distinct ethnic groups with their own languages. This makes the investment base for individual investors to be large and complex. (Purba, 2011) found mixed results when analyzing the existence of heard behavior in the Indonesian market. The existence of heard behavior, according to the finding from this article, were dependent of the performance of the market. Heard behavior was found to exist when there were large rallies in the market but not when there were extreme movements.

According to figures from the International Monetary Authority the Indonesian economy grew a $5.0 \%$ in 2016 and had an average GDP growth for the period analyzed in this article (2010-2016) of 5.6\%, which was smaller than the average growth rate for developing Asia (7.4\%). There appears to be some relatively clear linkages between the stock market and the economy in Indonesia. In fact, (Karim, 2014) concluded that stock market volatility in Indonesia impacts the exchange rate, and hence overall economy, in the country. The author found no indications of the volatility in the exchange rate actually impacting the stock market. This results partially contradicts (Rhami, 2016). According to (Rhami, 2016) exchange rate volatility did have some impact on stocks. The Indonesian stock market shares some characteristics with international markets. For instance, market participants, similarly to the case in many other countries, seem to consider stock dividends as an important factor behind the performance of a stock (Kent, 2009). Interest rates are another factor, similarly to other international markets, that has a significant impact on stock performance in Indonesia (Sutrisno, 2017), (Rhami, 2016).

Some market abnormalities, like the January effect (Haug, 2006), have been studied in the Indonesian market. (Simbolon, 2015) found that there was no apparent January effect in the Indonesian market. This analysis was done at a single company level for 12 firms. Another market abnormality studied was the Monday effect (Wang, 1997) (Nageswari, 2011). The Monday effect is an interesting application of phycology into the investment world. In principle there should be no statistically significant difference between the returns in any given day of the week i.e., Monday having lower or higher returns than Tuesday, but this is an occurrence seem in some markets. The results from (Rokhim, 2015) indicate that there is evidence to support the hypothesis that there is a Monday effect in the Indonesian market.

\section{Methodology}

Daily closing value for the MSCI indexes for small and large capitalization companies in Indonesia were obtained from Bloomberg for the period from 2010 to 2016. Using data from the same index compiler (MSCI) was done intentionally to try to maximize data consistency. There is no overlap among the constituents of both indexes. The MSCI Large Capitalization Indonesia Index ("large capitalization index") has, as of end of 2016, 16 components and according to estimates from MSCI accounts for approximately $70 \%$ of the total market capitalization of the Indonesian market with a median company size of approximately 3.1 USD billion in 2016. The MSCI Small Capitalization Indonesia Index ("small capitalization index") has, as of end of 2016, 54 components and accounts for approximately $14 \%$ of the market capitalization of the total market with a median company size in 2016 of approximately 279 USD millions. Both indexes are compiled by MSCI.The end of day closing values for the indexes were transformed into daily indexes returns. The logarithmic returns were also obtained. It is a common assumption that logarithmic returns are normally distributed but this was not the case for the indexes analyzed during the 2010-2016 period. In order to establish if the return and logarithmic return distributions were normally distributed an Anderson-Darling and ba Lillie test were performed in both indexes (small and large capitalization) and using both, returns (Table 1) and (Table 2) and logarithmic returns (Table 4 and 5). The results from the tests are similarly. For all the four cases the assumption that the data come from a normal distribution was rejected at a 5\% significance level. The only exception was 2016. The logarithmic return for the small capitalization index according to the Anderson Darling test did followed a normal distribution that year. The results from the Lillie test were consistent. In 
the case of the return an inconsistency was found between the results for the Lillie test and the Anderson Darling test. According to the Lillie test the returns in 2016 do follow a normal while the Anderson Darling test suggest that they do not.

Then a Wilcoxon test (Table 3) was done comparing the data for the entire 6 year period for both indexes. The null hypothesis in this test was that the data come from a distribution with the same median. At a $5 \%$ significance the null hypothesis of equal means cannot be rejected. All the tests for both the returns and the logarithmic returns, unless explicitly mentioned otherwise, were performed at a 5\% significance level.

Table 1. Anderson Darling test for logarithmic returns

\begin{tabular}{cccccc}
\hline Large cap & h & P & Small cap & H & p \\
\hline $\mathbf{2 0 1 0}$ & 1 & $5.0 \mathrm{E}-4$ & 2010 & 1 & $5.0 \mathrm{E}-4$ \\
$\mathbf{2 0 1 1}$ & 1 & $5.0 \mathrm{E}-4$ & 2011 & 1 & $5.0 \mathrm{E}-4$ \\
$\mathbf{2 0 1 2}$ & 1 & $5.0 \mathrm{E}-4$ & 2012 & 1 & $5.0 \mathrm{E}-4$ \\
$\mathbf{2 0 1 3}$ & 1 & $5.0 \mathrm{E}-4$ & 2013 & 1 & $5.0 \mathrm{E}-4$ \\
$\mathbf{2 0 1 4}$ & 1 & $5.0 \mathrm{E}-4$ & 2014 & 1 & $5.0 \mathrm{E}-4$ \\
$\mathbf{2 0 1 5}$ & 1 & $5.0 \mathrm{E}-4$ & 2015 & 1 & $5.0 \mathrm{E}-4$ \\
$\mathbf{2 0 1 6}$ & 1 & $5.0 \mathrm{E}-4$ & 2016 & 0 & $3.4 \mathrm{E}-1$ \\
\hline
\end{tabular}

Table 2. Lillie test for logarithmic returns

\begin{tabular}{cccccc}
\hline Large cap & $\mathbf{h}$ & $\mathbf{p}$ & Small cap & H & p \\
\hline $\mathbf{2 0 1 0}$ & 1 & $1.0 \mathrm{E}-3$ & 2010 & 1 & $1.0 \mathrm{E}-3$ \\
$\mathbf{2 0 1 1}$ & 1 & $1.0 \mathrm{E}-3$ & 2011 & 1 & $1.0 \mathrm{E}-3$ \\
$\mathbf{2 0 1 2}$ & 1 & $1.2 \mathrm{E}-2$ & 2012 & 1 & $1.0 \mathrm{E}-3$ \\
$\mathbf{2 0 1 3}$ & 1 & $1.0 \mathrm{E}-3$ & 2013 & 1 & $1.0 \mathrm{E}-3$ \\
$\mathbf{2 0 1 4}$ & 1 & $1.0 \mathrm{E}-3$ & 2014 & 1 & $1.0 \mathrm{E}-3$ \\
$\mathbf{2 0 1 5}$ & 1 & $1.0 \mathrm{E}-3$ & 2015 & 1 & $1.0 \mathrm{E}-3$ \\
$\mathbf{2 0 1 6}$ & 1 & $1.0 \mathrm{E}-3$ & 2016 & 0 & $5.0 \mathrm{E}-1$ \\
\hline
\end{tabular}

Table 3. Wilcoxon test for the logarithmic returns

\begin{tabular}{ccl}
\hline Indexes & p & h \\
\hline L2010 - S2010 & 0.1724 & 0 \\
L2011 - S2011 & 0.7579 & 0 \\
L2012 - S2012 & 0.8081 & 0 \\
L2013 - S2013 & 0.9452 & 0 \\
L2014-S2014 & 0.9826 & 0 \\
L2015 - S2015 & 0.3592 & 0 \\
L2016-S2016 & 0.7660 & 0 \\
\hline
\end{tabular}


Table 4. Anderson Darling test for returns

\begin{tabular}{cccccc}
\hline Large cap & h & $\mathbf{p}$ & Small cap & h & P \\
\hline $\mathbf{2 0 1 0}$ & 1 & $5.0 \mathrm{E}-4$ & 2010 & 1 & $5.0 \mathrm{E}-4$ \\
$\mathbf{2 0 1 1}$ & 1 & $5.4 \mathrm{E}-4$ & 2011 & 1 & $5.0 \mathrm{E}-4$ \\
$\mathbf{2 0 1 2}$ & 1 & $5.0 \mathrm{E}-4$ & 2012 & 1 & $5.0 \mathrm{E}-4$ \\
$\mathbf{2 0 1 3}$ & 1 & $5.0 \mathrm{E}-4$ & 2013 & 1 & $5.0 \mathrm{E}-4$ \\
$\mathbf{2 0 1 4}$ & 1 & $5.0 \mathrm{E}-4$ & 2014 & 1 & $5.0 \mathrm{E}-4$ \\
$\mathbf{2 0 1 5}$ & 1 & $5.0 \mathrm{E}-4$ & 2015 & 1 & $5.0 \mathrm{E}-4$ \\
$\mathbf{2 0 1 6}$ & 1 & $5.0 \mathrm{E}-4$ & 2016 & 1 & $5.0 \mathrm{E}-4$ \\
\hline
\end{tabular}

Table 5. Lillie test for returns

\begin{tabular}{cccccc}
\hline Large cap & $\mathbf{h}$ & $\mathbf{p}$ & Small cap & $\mathbf{h}$ & $\mathbf{P}$ \\
\hline $\mathbf{2 0 1 0}$ & 1 & $1.0 \mathrm{E}-3$ & 2010 & 1 & $1.0 \mathrm{E}-3$ \\
$\mathbf{2 0 1 1}$ & 1 & $1.0 \mathrm{E}-3$ & 2011 & 1 & $1.0 \mathrm{E}-3$ \\
$\mathbf{2 0 1 2}$ & 1 & $1.2 \mathrm{E}-2$ & 2012 & 1 & $1.2 \mathrm{E}-2$ \\
$\mathbf{2 0 1 3}$ & 1 & $1.0 \mathrm{E}-3$ & 2013 & 1 & $1.0 \mathrm{E}-3$ \\
$\mathbf{2 0 1 4}$ & 1 & $1.0 \mathrm{E}-3$ & 2014 & 1 & $1.0 \mathrm{E}-3$ \\
$\mathbf{2 0 1 5}$ & 1 & $1.0 \mathrm{E}-3$ & 2015 & 1 & $1.0 \mathrm{E}-3$ \\
$\mathbf{2 0 1 6}$ & 1 & $1.0 \mathrm{E}-3$ & 2016 & 0 & $5.0 \mathrm{E}-1$ \\
\hline
\end{tabular}

As previously mentioned one of the frequently mentioned reasons for a potential outperformance of small caps is the risk premium. In order to try to factor in risk the sharp ratios for every year from 2010 to 2016 were calculated (Table 6) and (Table 7). Standard deviation values used to calculate the Sharpe ratios were annualized. The risk free rate used was the 10 year Indonesian government bond. Using a Sharpe ratio is a frequently used tool for accounting for risk in the returns. In the case of Indonesia the risk free rate has remained at elevated values over the last few years, particularly when compared to develop markets such as Japan or Germany (Figure 1). The small capitalization index had negative Sharpe ration for three years while the large capitalization index only for one.

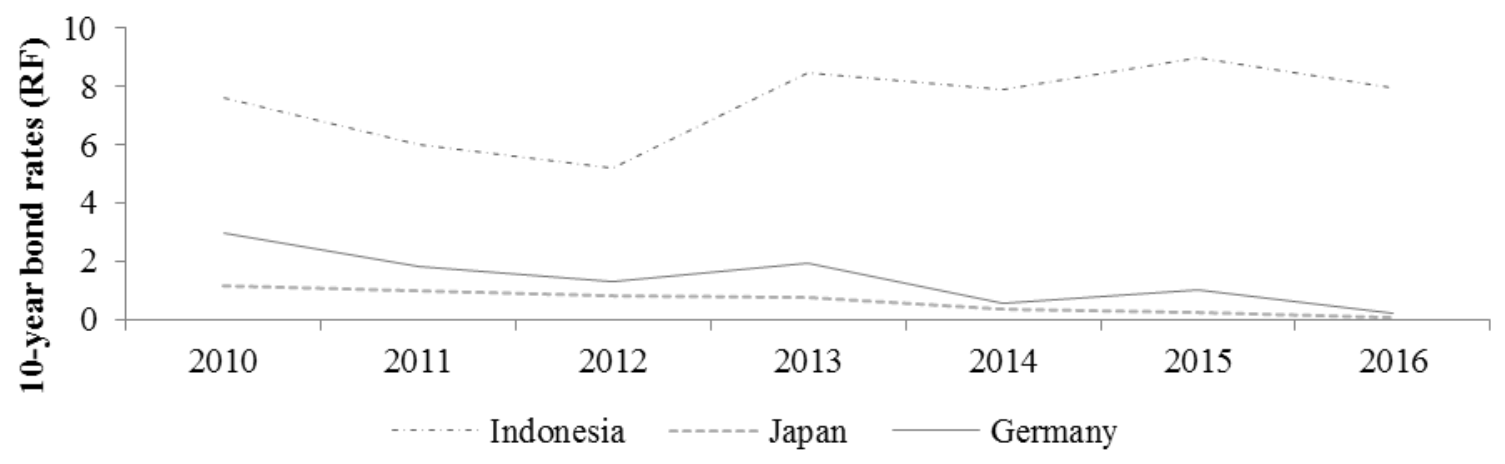

Figure 1. 10-year bond rates (risk free rate proxies) 
Table 6. Indonesia large cap

\begin{tabular}{|c|c|c|c|c|c|c|c|}
\hline & 2010 & 2011 & 2012 & 2013 & 2014 & 2015 & 2016 \\
\hline Returns (\%) & 23.7 & 8.6 & 6.7 & -3.1 & 29.6 & -10.8 & 16.4 \\
\hline S. Deviation (\%) & 23.2 & 26.9 & 16.5 & 26.7 & 17.9 & 22.8 & 18.0 \\
\hline Risk Free (\%) & 7.6 & 6.0 & 5.2 & 8.5 & 7.9 & 9.0 & 8.0 \\
\hline Sharpe & 0.7 & 0.1 & 0.1 & -0.4 & 1.2 & -0.9 & 0.5 \\
\hline
\end{tabular}

Table 7. Indonesia small cap

\begin{tabular}{lrrrrrrr}
\hline & \multicolumn{2}{c}{$\mathbf{2 0 1 0}$} & \multicolumn{2}{c}{$\mathbf{2 0 1 1}$} & \multicolumn{2}{c}{$\mathbf{2 0 1 2}$} & \multicolumn{2}{c}{$\mathbf{2 0 1 3}$} & \multicolumn{2}{c}{$\mathbf{2 0 1 4}$} & \multicolumn{2}{c}{$\mathbf{2 0 1 5}$} & \multicolumn{2}{c}{$\mathbf{2 0 1 6}$} \\
\hline Returns (\%) & 48.4 & -5.8 & 7.0 & -10.6 & 16.3 & -26.0 & 18.1 \\
S. Deviation (\%) & 24.7 & 26.6 & 15.6 & 24.5 & 16.7 & 19.4 & 16.5 \\
Risk Free (\%) & 7.6 & 6.0 & 5.2 & 8.5 & 7.9 & 9.0 & 8.0 \\
Sharpe & 1.7 & -0.4 & 0.1 & -0.8 & 0.5 & -1.8 & 0.6 \\
\hline
\end{tabular}

\section{Results}

For the period from 2010 to 2016 there was no appreciable small capitalization effect in the Indonesian market. In fact, the actual return for the large capitalization index for that period was $87.1 \%$, while the return for the small capitalization index was only $36.0 \%$. The returns and logarithmic returns of the index, according to an Anderson Darling and a Lillie test, do not follow a normal distribution. The only exception for this trend was the year 2016. In 2016 the logarithmic return according to both the Anderson Darling and the Lillie test, at 5\% significance, for small capitalization stocks did followed a normal distribution. For all the years analyzed, with the exception of 2016, the Anderson Darling and the Lillie test gave consistent results (indicating that the data did not follow a normal distribution). In 2016 the Anderson Darling and the Lillie test gave different conclusion for the normality of the returns regarding small caps with the Anderson Darling test rejecting the hypothesis of normal distribution while the Lille test supporting it. For the same year both tests suggest that the logarithmic return follows a normal distribution

Despite the relatively large difference in returns the hypothesis that the returns are statistically equal, using a Wilcoxon test, cannot be rejected at a 5\% confidence level. This is result is consistent for the entire period (Table 8 ) from 2010 to 2016, as well as if the test is done for every single year during that period (Table 6) and (Table 7). The biggest correction experienced by small capitalization stocks was a drop of $26.0 \%$ in 2015 , compared to a maximum loss (also in the same year) by large capitalization stocks of $10.8 \%$. All years when the small capitalization index had negative performances the large capitalization stock index had better results with even a gain of $8.6 \%$ in 2011 when the small capitalization index lost 5.8\%. For three of the six years analyzed small caps had a better performance than large caps. From a risk adjusted point of view the Sharpe ratio of small caps was higher in two years, 2010 and 2016. In both of those years the Indonesian market had very strong performances. The point estimate for the Sharpe ratio in 2012 was approximately equal for both indexes. The results seem to suggest that the hypothesis that there is a small capitalization effect, understood as a better performance in the stock market of small companies over large companies, cannot be accepted in the Indonesian market for the period analyzed.

Table 8. Wilcoxon for logarithmic returns from 2010 to 2016

\begin{tabular}{ccc}
\hline Indexes & h & P \\
\hline Large vs. Small cap & 0 & 0.757
\end{tabular}

\section{Discussion}

The Indonesian market, being a frontier country, might have characteristics that are rather different from other developed or even emerging markets. There seems to be no indication that there is an outperformance of small capitalization stocks in the Indonesian market when compared to large capitalization stocks. This is for instance different to the results obtained for Thailand (Alfonso, 2016). The results were consistent when analyzing the entire 
period, from 2010 to 2016, or every year independently. These results did not change when the risk adjusted performance of the indexes were compared. Another conclusion is that the returns for the small capitalization index and the large capitalization index do not follow a normal distribution. The same results was found for the logarithmic returns. The only year with less conclusive results regarding the normality of the distributions was 2016.

\section{References}

Alfonso Gerardo "Gerry" Perez. (2017). Company size effect in the stock market of Thailand. International Journal of Financial Research, 8(3), 105-110. https://doi.org/10.5430/ijfr.v8n3p105

Andiantro Yanuar, \& Mirza Adrian Rishad. (2016). A testing of efficient markets hypothesis in Indonesia stock market. Procedia - Social and Behavioral Science, 219. https://doi.org/10.1016/j.sbspro.2016.04.048

Andrikopoulus Panagiotis, Daynes Arief, Latimer David, \& Pagas Paradkevas. (2008). Size effect, methodological issues and "risk-to-default": evidence from the UK stock market. The European Journal of Finance, 14(4). http://dx.doi.org/10.1080/13518470802042070

Collins Bruce, \& Fabozzi Frank. (1990). Considerations in selecting a small-capitalization benchmark. Financial Analyst Journal, 46(1). https://doi.org/10.2469/faj.v46.n1.40

Fama Eugene, \& French Kenneth. (1993). Common risk factors in the returns on stock and bonds. Journal of Financial Economics, 33. https://doi.org/10.1016/0304-405X(93)90023-5

Haug Mark, Hirschey Mark. (2009). The January effect. Financial Analyst Journal, 62(5). https://doi.org/10.2469/faj.v62.n5.4284

Karim Bakri Abdul, Sea Loke Phui, \& Karim Zulkefly. (2014). The impact of macroeconomic volatility on the Indonesian stock market volatility. International Journal of Business and Techno Entrepreneurship, 4(3).

Mageswari, P., Selvam, M., \& Gayathri, J. (2011). Analysis of Monday effect in the Indian stock market. Research Journal of Business Management. https://doi.org/10.3923/rjbm.170.177

Moh Benny Alexandri. (2014). Stock investment analysis: case in Indonesia stock exchange (IDX). International Journal of Business and Management Review. 3(1). Retrieved from http://repository.unpad.ac.id/23522/

Nurazi Ridwan, Santi Fitri, \& Usman Berto. (2015). Tunneling: evidence from Indonesian stock exchange. Asian Academy of Management Journal of Accounting and Finance, 11(2). Retrieved from http://repository.unib.ac.id/11615/

Pasaribu Rowland Bismark Fernando. (2009). Stock portfolio with Fama-French model in Indonesian stock exchange. Journal of Accounting \& Business, 9(1).

Purba Adi Vithara, \& Faradynawati Ida Ayu Agung. (2011). An examination of heard behavior in the Indonesian stock market. Indonesian Capital Market Review, 4(1). https://doi.org/10.21002/icmr.v4i1.985

Rhami Muskita, Azma Nurul, Muttaqin Aminullah Achmad, Jazil Thuba, \& Rahman Mahfuzur. (2016). Risk volatility measurement: evidence from Indonesian stock market. The Journal of Asian Finance, Economics and Business, 3(3). https://doi.org/10.13106/jafeb.2016.vol3.no3.57

Rokhim, R, \& Tanuwijaya, H. (2015). Market Anomalies and Intraday Return Indonesia Stock Exchange. International Journal of Economics and Management Science. https://doi.org/10.4172/2162-6359.1000253

Simbolon Ika Pratiwi. (2015). January effect of stock returns in Indonesia. The unconditional method and the conditional method. International Business Management, 9. https://doi.org/10.3923/ibm.2015.1221.1225

Sutrisno Bambang. (2017). Macroeconomic variables and sectorial indices: case in the Indonesian stock exchange. Etikomi, 16. https://doi.org/10.15408/etk.v16i1.4323

Switzer Lorne. (2012). The relative performance of small cap firms and default risk across the business cycle: international evidence. International Journal of Business, 17.

Wang Ko, Li Yuming, \& Erickson John. (1997). A new look at the Monday effect. The Journal of Finance, 52(5). https://doi.org/10.1111/j.1540-6261.1997.tb02757.x 